\title{
Samuël Kruizinga Struggling to Fit in. The Dutch in a Transnational Army, I936-I939
}

During the Spanish Civil War (I936-I939), over 32.000 foreign fighters fought to defend the Spanish Republic from a military uprising that was led by Francisco Franco and strongly supported by Fascist Italy and Nazi Germany. These foreign fighters have fascinated historians ever since, but historical and societal interests have surged since the start of the wars in Syria and Iraq, which have once again drawn significant numbers of military volunteers from abroad. ${ }^{1}$

Increasingly, historians as well as social and political scientists point to these foreign fighters as a specific, violent brand of transnational activists, pursuing contentious politics outside the usual political arenas and legal norms in defence of a shared identity existing beyond the territorial, juridical, economic, political, and sociocultural boundaries of the nation-state. ${ }^{2}$ Likewise, historians of the «International Brigades» in the Spanish Civil War invariably point to a shared set of experiences by its members, irrespective of their country of origin: the poverty and social injustices of the I930s and a profound fear of the rise of Fascism abroad and at home that was combined to create a truly transnational connection between peoples of different origins, which was activated by the Spanish Civil War and which melded them together in an ideologically motivated transnational citizen's army. ${ }^{3}$

1 Recent research into the phenomenon include N.Arielli / D. Rodogno, «Transnational Encounters: Hosting and Remembering Twentieth-Century Foreign War Volunteers», in: Journal of Modern European History I4 (2016) 3, 3I5-320; A.de Guttry / F. Capone / C. Paulussen, «Introduction», in: idem (eds.), Foreign Fighters under International Law and Beyond, The Hague, 20I6, I-5.

2 R.Gildea/A.Tompkins, «The Transnational in the Local: The Larzac Plateau as a Site of Transnational Activism since I970», in: Journal of Contemporary History 50 (20I5) 3, 58I-605; S.Tarrow, The New Transnational Activism, Cambridge 2005; D.della Porta/H.Kriesi, «Social Movements in a
Globalizing World: An Introduction», in: idem/ D. Rucht (eds.), Social Movements in a Globalizing World, Houndsmills I999, 3-22; D. Malet, Foreign Fighters. Transnational Identity in Civil Conflicts, Oxford 2013.

3 Recent examples include R.Skoutelsky, L'espoir guidait leur pas. Les voluntaires français dans les Brigades internationales 1936-1939, Paris I998; M.Zuehlke, The Gallant Cause. Canadians in the Spanish Civil War 1936-1939, Mississauga 2007 (I996); R. Baxell, Unlikely Warriors, London 20I2; N.Ulmi/P. Huber, Les Combattants suisses en Espagne républicaine (1936-1939), Lausanne 200 I. 
In this article, I will show that for some International Brigadiers, the transnational connections did not come as easily or naturally as this narrative suggests. In doing so, I aim to connect my analysis of the «transnational» Brigades with a recent trend in the studies of transnational (activist) movements. Both Pierre-Yves Saunier and Kiran Klaus Patel have recently suggested that historians of the transnational, in their apparent desire to refocus the level of analysis away from the state, have a tendency to simply ignore the immense abilities of the nineteenth- and twentieth-century state, its agents and its supporters to frame the relationship between its citizens and the wider world, not only in a legal way but also in a cultural and emotional sense. ${ }^{4}$ This article will therefore highlight the conflict between the two «imagined communities» of the national and the transnational in the context of the International Brigade experience. ${ }^{5}$

The article will do so by focusing on the experiences of the approximately 800 Spanish Civil War volunteers from the Netherlands. In their home country, a curiously specific discourse on the relationship between the Spanish Civil War and the conceptions of «Dutchness» steered the mobilisation for Spanish Civil War volunteers in a direction that was markedly different from that in other Western European countries. In Spain, meanwhile, tensions between the Dutch and the German International Brigaders interfaced with the difficult relationship between the Dutch Communist Party and the Communist International (Comintern). Finally, the legacy of their Spanish Civil War experiences continued to play an overriding role in the Dutch International Brigade veterans' fight against the Nazi occupation at home during the Second World War.

\section{1. «Holland is here!»}

One of the first Dutch fighting volunteers in the Spanish Civil War was the Dutch novelist Jef Last. A recent convert to Communism, Last had by 1936 began to doubt his newfound convictions. He was critical of the Moscow Show Trials against the old Bolshevik guard and the prohibition of same-sex intercourse in the new Soviet Union constitution. Last, who was bisexual, regarded both the trials and the constitutional changes as fundamental betrayals of the principles of class solidarity that had drawn him to Communism in the first place. Even two pilgrimages to Moscow in I934 and I936 did little to restore his confidence in the Soviet system. Therefore, in order to

4 P.-Y.Saunier, «La secrétaire générale, l’ambassadeur et le docteur: un conte en trois épisodes pour les historiens $\mathrm{du}$ 〈monde des causes〉 à l'époque contemporaine», in: Monde(s): Histoire, Espaces, Relations I (20I2), I-29; K. K. Patel, «Überlegungen $\mathrm{zu}$ einer transnationalen Geschichte», in: Zeitschrift für Geschichtswissenschaft 52 (2004) 7, 626-645. See also J. Reinisch, «Agents of Internationalism», in: Contemporary European History 25
(2016) 2, I95-205; P.Clavin, «Defining Transnationalism», in: Contemporary European History I4 (2005) 4, 42I-439.

5 B.Anderson, Imagined Communities. Reflections on the Origin and Spread of Nationalism, revised edition, London, New York 20I6. A distinct but similar point is made in L.A. Kirschenbaum, International Communism and the Spanish Civil War. Solidarity and Suspicion, New York et al. 2015. 
renew his faith in what he considered to be the basic tenet of communism - the working class's fight against oppression -, he decided to travel directly from his second Moscow visit to Spain, where the Civil War had just broken out. ${ }^{6}$ Arriving in Spain in late September 1936 , he joined a Spanish workers' militia - Last, who was fluent in French, apparently had little trouble learning Spanish. In field reports that he sent to the Dutch Communist Party newspaper, De Tribune, Last lauded the spirit of the international camaraderie that he had found even in the darkest days of the fight to keep Madrid out of the hands of Franco's forces. Defeat was not an option, he wrote on I6 November 1936, as victory for the Fascists would mean «great difficulties» for «the working class», «here as well as in Holland». Four days later, he added: «The Madrid proletariat knows that it stands on the barricades not just for their own sake, but for the sake of all other peoples as well. Are the Dutch aware of what is at stake?» ${ }^{7}$

Last was hardly the only one advocating the case of the Spanish Republic in the Netherlands. Already on 24 July I936, the Dutch section of the International Red Aid (IRA) had started a funding drive in support of the Spanish Republican forces, which faced a «a Fascist coup d'état' committed by <oathbreaking generals with the help of [...] foreign legionnaires, supported by foreign fascists Powers $\gg{ }^{8}{ }^{8}$ Later, the IRA's newspaper added that the «enemies of the Spanish people» are «our enemies too», ${ }^{9}$ and darkly hinted that the German «volunteers» who had come to Franco's aid might one day «swell the ranks of [Anton] Mussert», the leader of the Dutch National-Socialist Movement. ${ }^{10}$ On 28 August 1936, the IRA had already raised Fl. 4500 (a sum roughly equivalent to the mid-20I7 purchasing power of $€ 45.000$ ) in support of the Spanish Republic medical services. ${ }^{11}$ The IRA was soon joined by a new Aid Spain Committee (ASC), a Communist front organisation which featured left-leaning socialists and labour union representatives in prominent positions in order to appeal to a broader anti-fascist sentiment. After a separate funding drive, ASC dispatched Io.000 emergency bandages, which were shipped to Spain in early August $1936 .{ }^{12}$ The ASC would henceforth concentrate on sending money and supplies to Spain, while the IRA would, from autumn 1936 onwards, focus on a new, secret mission: Its Amsterdam offices were designated by the Dutch Communist Party leadership as the recruitment headquarters for the International Brigades in the Netherlands.

6 International Institute for Social History, Amsterdam (IISH) ARCHoo799/6: Jef Last to André Gide, 29 August I936.

7 J.Last, Brieven uit Spanje, Amsterdam 1936, 4748.

8 The Russian State Archive of Socio-Political History, Moscow (RGASPI) 539/3/583: Proclamation by IRA, «Aan het Nederlandsche Volk», I5.8.1936.

9 «Onze steunbeweging voor Spanje. Wij gaan door!
Wij moeten de volksmassa's in beweging brengen!», in: Afweerfront tegen oorlog en Fascisme. Orgaan van alle anti-fascisten I9 (I936), 2.

10 De Tribune, 05.I2.I936.

11 RGASPI 539/3/583: Bericht über die Spanien-Kampagne, I9.9.1936.

12 RGASPI 539/3/583: Proclamation by IRA, «Aan het Nederlandsche Volk», I5.8.1936. 
But despite the apparent early successes of their efforts to raise awareness and sympathy for the Spanish Republican cause, the IRA recruitment campaign was off to a very rocky start. In early December I936, De Telegraaf, a leading right-wing daily, printed a series of articles based on the testimony of an anonymous source that was meant to expose the recruiting methods used by Dutch communists. The articles focused on the efforts by Isaac Johan Nooter, a leading member of a communist-affiliated maritime transport union, to recruit young unemployed harbour hands by luring them to an Amsterdam bar and promising them a cash reward and a steady job in Spain. He then, De Telegraaf reported, brought them to the Avenue Mathurin Moreau in Paris, where the Comité de Defensa del Pueblo Español proceeded to send the Dutchmen to the Madrid fronts; obviously, no job or money was forthcoming. ${ }^{13}$ One of the recruited, quite possibly De Telegraaf's anonymous whistle-blower, apparently had second thoughts before reporting to the Comite and reached out to the Dutch consul general in Paris instead, who in turn notified the Amsterdam police. Nooter was arrested on Christmas Eve, but released early in the following year due to a lack of evidence. He claimed that he had acted in good faith by directing unemployed countrymen to an opportunity for gainful employment abroad, and could not have known of the Comités intentions. ${ }^{14}$ De Telegraaf and other leading Dutch newspapers, especially those with a conservative or right-wing slant, expressed their disappointment over the failure to prosecute Nooter, and demanded immediate legal action to be taken against the recruitment for the Spanish Civil War in the Netherlands. ${ }^{15}$ Moreover, they launched an investigation into any and all reports of Dutch or foreign agents who were luring innocent Dutch victims to Spain under false pretences. A steady stream of newspaper reports - some true, some exaggerated, and some outright lies - only seemed to confirm to the average Dutch newspaper readers that their country had turned into the European epicentre for the smuggling not only of people, but also of money and weapons, into the Spanish cauldron. ${ }^{16}$

Right-wing press campaigns against recruiting for the Spanish Republican cause, were widespread through all the European democracies. ${ }^{17}$ But the Dutch government of the time - a centre-right Christian-Liberal coalition headed by Hendrik Colijn - was particularly susceptible to these influential newspapers' criticisms. In

13 De Telegraaf, 9.I2.I936, Ochtendblad, «Werk op een schip? NEEN, NAAR HET FRONT!»; 8.12.1936, Avondblad, «Ronselaars voor Spanje in ons land!»

14 Dutch National Archives, The Hague (DNA) 2.09.99/I70: Public Prosecutor Amsterdam to Attorney General Amsterdam, 5.2.I937.

15 De Telegraaf, 24.I.I936, Avondblad, «Ronselarij in ons land; Nooter gearresteerd»; De Telegraaf, 25.I2.I936, «Ronselarij voor het roode leger in
Spanje»; De Standaard, 25.I2.I936, Ochtendblad, «Een communistische ronselaar voor den Spaanschen krijgsdienst te Amsterdam aangehouden».

16 De Tijd, 24.7.I937, «Communistische activiteit in ons land neemt toe. Duister gewoel van partij en organisaties».

17 See for example H. García, The Truth about Spain! Mobilizing British Public Opinion, 1936-1939, Brighton et al. 2010, 27-29; R. Skoutelsky, L'espoir, I34. 
August 1936, Colijn's government had co-signed the Non-Intervention Agreement aimed at localising the Spanish Civil War and at preventing it from causing a general European war. Together with the other signatories, the Dutch agreed in early I937 to implement stringent measures aimed at preventing foreign volunteers from joining either the Republic or the Francoist uprising. Actively supporting Non-intervention also fit neatly with the official Dutch narratives that promoted the utility of Dutch neutrality in the context of preserving European peace and of reconstructing the international community following the shock of the First World War. ${ }^{18}$ The continuing rumours surrounding the transportation of Dutch volunteers and weapons clashed with these narratives, and, to make matters worse, also threatened to upset the delicate relations with the Netherlands' next-door neighbour, Nazi Germany. ${ }^{19}$

A third element that would shape the environment in which the IRA recruiters for the International Brigades operated were the upcoming general elections, scheduled for May I937. Inspired partly by the notion that the Netherlands was beset by «foreign agents» luring innocents to their slaughter, and partly by the notion of a unique Dutch international mission in maintaining European peace, one of the dominant themes of the electoral campaign was that of the Dutch identity. Most mainstream political parties, even the Socialists, argued that the Dutch identity was under threat from political extremism. Global political uncertainty, the social ills of modernism, and, above all, the insidious effects of the continuing economic crisis were seen as the primary infectants, according to an analysis of Dutch politics by the head of the secret service: «Its victims are those who lack both basic principles and real national feeling, and therefore lack the ability to withstand the infections' dangerous attacks. As a result, these peoples are drawn to a German Gefreiter, and ignore the warnings of the stout Dutch militiaman; they lend their ears to the blustering and deceitful talk of the Russian agitator, but are deaf to the reasoned arguments of their own pastor. [...] We live in times of plague, and need to be extraordinarily careful.» ${ }^{20}$

The narrative of political extremism as a foreign threat, its adherents being infected by the poisonous rhetoric of Hitler and Stalin, resonated powerfully in the Netherlands, where the political establishment was still haunted by the spectre of revolution following an aborted Socialist putsch in November I9I8. ${ }^{21}$ It also fed back into Dutch reporting on Spain. There, the bacteria had been allowed to spread and with disastrous consequences. «When what happens now in Spain would spread

18 See S. Kruizinga, «Small, Medium, or Large? Domestic Discourses on the Size of the Netherlands and their Foreign Policy Implications, I815-1939", in: Diplomacy and Statecraft 27 (2016) 3, 420-436.

19 DNA 2.05.03/1682, folder «Werving vrijwilligers Spanje»: Dept. of Justice to Dept. of Foreign Affairs, 2.3.I937; reply, II.3.I937.

20 Dutch Central Intelligence Service (CI) report no.
39649: Report of Meeting of the Central Intelligence Service with Police Contacts, 27.II.I936. The CI reports can be found online at http://resources.huygens.knaw.nl/rapportencentraleinlichtingendienst.

21 P. Moeyes / S. Kruizinga / W. Klinkert, Nederland neutraal. De Eerste Wereldoorlog, 1914-1918, Amsterdam 2014, 366-369, 446-449. 
over the continent», argued De Tijd, «the entirety of Europe would be in the grip of a terrible madness. The nervous systems of the Spanish people have been tremendously compromised. Their brains lack the capacity for normal, rational thought. Everything and everyone is off balance, confused, abnormal.» ${ }^{22}$

It is therefore unsurprising that Dutch support for stringent legal measures against recruitment and volunteering for Spain, which went considerably further than those enacted in Belgium, Britain, and France, was nearly unanimous. ${ }^{23}$ The Dutch secret services and municipal political intelligence services quickly honed in on the Dutch chapter of International Red Aid as the unofficial headquarters of this massive undertaking, and subjected its leading members and suspected recruiters to intense scrutiny. ${ }^{24}$ Moreover, following the failed prosecution of the recruiter John Nooter, the Ministry of Justice went hard at work to draft the new legislation to increase the chances of a successful prosecution. An Order in Council of 4 March 1937 explicitly outlawed the transportation of either people or weapons to Spain, whilst an even more far-reaching Order of II June I937 stated: «Any act, which is undertaken with the motive of joining any of the belligerent forces in Spain, or allowing others to do so, will henceforth be illegal.» This Order in Council was the strongest signifier yet that the Dutch judiciary was targeting not only foreign fighters bound for Spain, but would focus primarily on the apparatus that was created to infect impressionable and vulnerable men with the dangerous foreign bacillus of violent transnational Communism. Moreover, the new Dutch Government - once again headed by Colijn but now supported exclusively by a new Christian Right majority - hoped that the new legislation would serve as a powerful deterrent. ${ }^{25}$

The changing political and legal circumstances seriously complicated the Dutch Communist Party's recruiting efforts. The International Red Aid's offices were closely watched, and serious efforts were made by the local police to infiltrate the recruiter networks. This led to some early, and well publicised, successes, such as the arrest of Cornelis van Soolingen, who ran the recruiting network in the North Holland prov-

22 De Tijd, I8.6.I937, «Spanje is een roode vlek op de landkaart». Similar sentiments were echoed in Parliament: Lower House Minutes (Handelingen van de Tweede Kamer der Staten-Generaal, HTK) I936-I937, I0.12.1936, 956 (Wendelaar).

23 De Telegraaf, 25.5.I937, Avondblad, «Vóór de stembus. Geen experimenten». For the relative failure of legal measures enacted against material support for any party in the Spanish conflict in other Western European democracies, see for example T. Buchanan, Britain and the Spanish Civil War, Cambridge I997, 55; Skoutelsky, L'Espoir, I44, I33; É. David, «La condition juridique des volontaires belges pendant la guerre d'Espagne (I936-I939)», in: La Revue belge d'Histoire contemporaine I-2 (1987), 39-80. Only in Switzerland did legal meas- ures seem to achieve a similar degree of support and scope: C.Fussinger, «L'attitude des autorités vaudoises à la lumière des dossiers de la police de Sûreté», in: M.Cerutti / S. Guex/ P. Huber (eds.), La Suisse et l'Espagne de la République à Franco (1936-1946), Lausanne, 200I, I53-I89.

24 CI no. 41083, 28.I.I937.

25 DNA 2.05.03/roo6, folder «Verbod vervoer wapens naar Spanje»: Foreign Affairs Dept. to Queen Wilhelmina, 26.2.1937; DNA 2.05.57/1352: «Toelichting voor den Nederlandschen consulairen ambtenaar op het K.B.van 4 Maart I937», n.d.; NA 2.05.03/I682, folder «Werving vrijwilligers Spanje»: Foreign Affairs Ministry to Justice Ministry, II.3.I937; «Aanteekening voor Z.E.», n.d. 
ince and who was responsible for transporting over forty Dutchmen to Spain. More often than not, these successes were made possible by information obtained from the deserters, who were a valuable source of information and who were very keen to lay the blame for their illegal actions elsewhere. Their testimonies, which often featured horror stories of press-ganged and draconian discipline that in turn served to highlight to the police officers, the judiciary and the press how dangerous these recruiters for Spain really were, and how comparatively innocent their victims were. ${ }^{26}$

The Dutch Communist Party, meanwhile, had few weapons to strike back against, firstly, the «biological» rhetoric condemning foreign fighting as anti-Dutch, and secondly, the successful police actions against recruiters, both of which were bolstered by a narrative of the deserters as «victims». Moreover, the Tribune - renamed halfway through I937 as the Volksdagblad (or «People's Newspaper») in a conscious effort to appeal to a broader demographic than hard-core communists - could not openly call for more recruits, and needed to be careful lest the intense scrutiny over foreign fighters impact the Spanish relief campaigns organised by ostensibly non-partisan Aid Spain Committee. Moreover, the Dutch CP had to walk a fine line between advocating for Spain - seen as primarily a communist cause - and appealing to the entire working class - large parts of which voted socialist, not communist - in order to further the establishment of a Dutch popular front. ${ }^{27}$ In order to resolve these dilemmas, the Communist daily - like its counterparts in other European countries - resorted to print letters of Dutch volunteers in Spain as their primariy means of reporting on the Civil War. These letters also functioned as a round-about recruitment call, emphasising that Republican Spain was not a Soviet satellite but an anti-fascist regime under threat, that victory in Spain was crucial for the maintenance of European peace and security, that Dutch volunteers cut popular figures in Spain on account of their bravery, and, crucially, that no one was being press-ganged into service. Most of all, readers were encouraged to think that there was a significant number of Dutchmen in Spain and that they constituted a vital part of the international army. ${ }^{28}$

To further counter the notion that going to Spain was «un-Dutch», Jef Last was asked to return from Spain in late December I936 to propagandise both the Spanish Republican cause in general and the International Brigades, which had been created the previous month. Upon his return to the Netherlands, he was detained at the border, tried, and found guilty of foreign fighting, which was illegal in the Netherlands. ${ }^{29}$ Unlike recruiting agent John Nooter before him, Last did not bother denying the

26 DNA 2.09.22/I68Io: Official report Haarlem police, I4.2.I938; NA 2.09.22/I68Io: Public Prosecutor Haarlem aan Attorney General Amsterdam, I6.3.1938.

27 See De Tribune, I5.I.I937; Het Volksdagblad, I5.II.I937; 27.I.I938.
28 Examples include letters printed in De Tribune, I9., 24., 25.2. and 8.3.I937; and in Het Volksdagblad, 24.4., 2I.5. and I4.IO.I937.

29 HTK I83I-I832, 05-O6-I832, 357. 
charges: He had published newspaper articles and even two books detailing his military experiences in Spain. As a consequence, Last lost his Dutch citizenship and had to surrender his Dutch passport. Suddenly finding himself as an alien in his own country, Last found it impossible to speak out in public about Spain, since nonDutch citizens were forbidden by law to engage in any political activity. He did manage to sneak across the Dutch border and to return to Spain, where, at the request of the Dutch Communist Party leadership, he continued to write about his experiences, which were published in a book in early I937. In it, he argued that far from having forsaken their «Dutchness», he and the other volunteers for Spain were quintessential Dutchmen. Recalling the Dutch struggle for independence in the Eighty Years' War (1568-1648), he argued that the Dutch Interbrigaders were the true successors of the mythical Sea Beggars who, like them, fought «inquisition, tyranny and injustice». ${ }^{30}$ Even the arch-enemy of the Sea Beggars, the bloodthirsty Spanish Duke of Alba, Last argued, had returned in the guise of Franco. «In a time when the Dutch bourgeoisie seems to have forgotten its historical legacy of fighting for democracy [...] and freedom», wrote Last, «we remember our past. It now falls to us to continue the Sea Beggars' legacy. The boys who went to Spain [...] preserved Dutch honour in the battles fought in Spain to save our own country [...] and with it the entire world». ${ }^{31}$

So, in the space of a few months, Dutch debates about the Spanish Civil War had meshed with larger discussions about Dutchness and the supposed alien nature of the ideological conflict fought out in Spain. Even the propagandists for the Spanish Republican cause in the Netherlands, as Last's rousing sentences demonstrate, had no option but to engage in a debate that became less about Spain and more about the Netherlands. The change, both in tone and contents, of the debate and the legal consequences it had in the Netherlands, was to have a real and lasting effect on the Dutch experience in the Spanish Civil War.

\section{2. "The Dutch Problem»}

Leo Klatser, a journalist for the Communist Party (CP) newspaper, left Holland for service in Spain in April I937. He arrived in Barcelona in May and wasted no time writing to his sister, Nora: «Spain is a beautiful country. The comradeship is exemplary [...]. Wine perfect and bountiful. There is no unemployment! Armaments in perfect condition. Comradeship beyond words!»32

In later letters, Leo would continue to emphasise international solidarity as well as the single-minded determination of the International Brigaders to fight «for Spanish democracy», and the carefree connections forged between its supporters irre-

30 J.Last, Over de Hollanders in Spanje, Amsterdam I937, 3 .

31 Ibid., I9. Written in late July, early August I937.
32 IISH ARCHo2806/04: Leo Klatser to Nora Klatser, I8.5.I937. 
spective of national context - exemplified by his frequent mentions of a Spanish «lady friend», Conchita. ${ }^{33}$ But apparently, Leo's skills as a photographer and a journalist made the Dutch CP leadership hesitant to allow him to travel to Spain. He was only given permission to go to Spain after the CPN electoral caucus in Easter I937. Upon arrival in Albacete, he was immediately sequestered by a Dutch CP representative, who was operating under the alias «Winter», and selected for cadre duty. He spent the rest of the war away from the fronts, first on photography duty for the Republican Army medical services' newspaper, and then working for the mapping services of the Republican general staff, working closely with Austrian and German colleagues. He continued to do staff work until February I939, when he was forced to return to Holland following Franco's invasion of Catalonia. ${ }^{34}$

Klatser's Spanish tour is not that unusual. Higher-ranking CP members who volunteered for Spain were often kept in reserve in order to keep them out of potential harm, and to make room for non-Communist anti-fascists. More generally, Klatser's motivations and background are also rather typical for both European and, more specifically, Dutch Interbrigaders. His experiences have been recorded in the late I970 and the early I980 as part of an oral history project by the Free University of Amsterdam, during which, in addition to Klatser, some twenty surviving veterans were extensively interviewed. When asked about their background and motivations, many of these volunteers told a remarkably similar story, which would be intimately familiar to readers of histories of national contingents of the International Brigades. That story usually starts with experiences of unemployment and disillusionment with the current political climate, coupled with a profound fear of Fascism both abroad and at home, and some earlier practical experience in left-wing political activism. ${ }^{35}$ However, one additional element is unique to these interviews of Dutch International Brigaders: Many looked back at their experiences with German exiles in the Netherlands as integral to their outlook on the Spanish conflict and their decision to join up.

Following Hitler's ascension to power in I933, a significant number of German communists fled Nazi persecution by going to the Netherlands, usually illegally. ${ }^{36}$ The Dutch section of the International Red Aid had been very active in organising a sort of underground railroad for ferrying German communists into the Netherlands and hiding them from the Dutch police who would detain and deport them. ${ }^{37}$ These contacts with exiled Germans, as shown by the veterans' interviews, often made a

33 IISH ARCHo2806/04: Leo Klatser to Nora Klatser, 7.9.1937.

34 ARCHo2806/4I: Interview Leo Klatser, 6.3.I984.

35 See, for example, P.N.Carroll, The Odyssey of the Abraham Lincoln Brigade. Americans in the Spanish Civil War, Stanford I994, I4-48; and R. Baxell, Unlikely Warriors, 3-40, 55 .

36 B.Herlemann, «Het Exil als operatiebasis. De
Duitse communistische emigratie in Nederland, I933-I945", in: K. Dittrich (ed.), Nederland en het Duitse exil 1933-1930, Amsterdam, I982, I27-I43.

37 «Redt Franz Schmalenbeck! Het uitleveringstractaat met Duitsland moet worden opgezegd», in: Afweerfront tegen oorlog en Fascisme. Orgaan van alle anti-fascisten 2 (January I936), 3. 
lasting impression. Anton Michels, barely I8 years old when he went to Spain in I938, related how German refugees bared their bruised backs to him so that he could see for himself the lasting effects of Nazi torture. ${ }^{38}$ Others had been active in the IRA underground railroad, on occasion visiting Germany to spread the illegal communist newspaper Die Rote Fahne and other propaganda leaflets, or to visit communists who had chosen to remain in Germany. ${ }^{39}$ Arie van de Poelgeest, for example, used his job in the Rhine shipping trade to smuggle Communist propaganda (and, more profitably, Belgian cigarettes) into Germany, whilst Adriaan van Dijk hid messages from the German Communist Party in exile's leadership in the frame of his bike and simply pedalled across the Dutch-German border under cover of night. ${ }^{40}$

The interviews with the Dutch IB veterans make clear that working with the IRA in the period leading up to the Spanish Civil War provided the veterans with two key benefits. First and foremost, they knew German, either having had prior experience with the language or learning it to aid communication with the German Exil. Secondly, their second-hand experience with Nazi oppression and torture had made them acutely aware of the dangers of fascism. Tellingly, many of them recounted incidents of fighting members of the Dutch National Socialist Movement (NSB) in the streets. Indeed, the IRA weekly newspaper frequently compared the similarity between the NSB's street rallies with those of the German Brownshirts' pre-I933, suggesting that the rallies were intended to incite riots while laying the blame on the Left, and use the ensuing chaos to fuel demand for a dictatorship to restore law and order. ${ }^{41}$ Intimate knowledge of the German Exil experience and fluency in German proved to be key assets in Spain, since most of the Dutchmen who travelled to Spain in I936 and I937 mainly ended up serving in German units as part of the XI Brigade. Their commanders and most of their political commissars were and spoke German; they were selected because they had military experience serving in the German Army, and, in some cases, had even fought in the First World War. ${ }^{42}$

Piet Laros, a former anarchist and recent convert to Communism, had travelled to Spain in August I936 - by biking (!) to Paris on a whim, where he chanced upon a group of German communists who helped him to cross the Franco-Spanish border -, and generally enjoyed a good relationship with his German fellow fighters. He, too, had direct experience with German exiles and spoke some German. Laros's

38 ARCHo2806/4I: Interview Anton Michels, I9.I2. I983.

39 ARCHo2806/44: Interview Arie van de Poelgeest, 3O.II.I983.

40 ARCHo2806/35: Interview Adriaan van Dijk, 7. and I4.I2.1983.

41 ARCHo2806/33: Interview Siep Adema, 25.5. I984; «Terreur in Spanje? Plompe verhalen van de N.S.B.-er», in: Afweerfront tegen oorlog en Fascisme. Orgaan van alle anti-fascisten Io (I936), 4.
42 S.Luitze, «Erfahrungen eines Holländers in der XIII.Brigade», in: A. Kantorowicz (ed.), «Tschapaiew». Das Bataillon der 21 Nationen. Dargestellt in Aufzeichnungen seiner Mitkämpfer, Madrid, I938, 253-255; H.Dankaart et al., De oorlog begon in Spanje. Nederlanders in de Spaanse Burgeroorlog 1936-1939, Amsterdam I986, 92-93; G.Vanter, Nederlanders onder commando van Hollander Piet in Spanje, Amsterdam I939, 43-54. 
standing with his German squad mates increased significantly when a photograph of him, wounded in action and supported by two beautiful Spanish nurses, was taken and circulated in IB propaganda material with the tongue-in-cheek caption, «Der Holländer Piet wird abtransportiert» - «Dutchman Pete is being taken away», suggesting that he might be subject to more than purely medical attention. «Dutchman Pete», however, conceded during his I980 interviews that not all his dealings with the Germans in Spain had been positive ones. He struggled with the language and had profound difficulties with what he called the «Prussian militarism» that, according to him, was deeply ingrained in all Germans, even in German socialists and communists. Almost fifty years after serving in Spain, he vividly recalled how much he hated his first German commanding officer, a Reinhard Hofmann, and his endless drills. «All that shouting, we just couldn't take it. At least, I couldn't, and I was the only Dutchmen at first. But later the other Dutchman told me they felt the same.» And it was not just this commander. German IB men as a whole, «Pete» offered, were «fanatics, the lot of them»: bereft of a home of their own and intimately familiar with the cost of defeat, they pursued victory at all costs and accused anyone who they felt did less of «cowardice». 43

Those with some experiences with the German Exil could understand their German fellow soldiers' motivation, either intellectually or emotionally, and were therefore better able to adapt to fighting in German units. However, most of the Dutchmen that had come to Spain in I936 and I937 - about 350, a comparatively low number in regard to most other Western European countries - did not. This is not only demonstrated by the anecdotal evidence provided by men such as Piet Laros, ${ }^{44}$ or by the many stories of abuse at German hands told by Dutch deserters, but also, crucially, by testimony from the Dutch Communist Party itself. In November I937, Jan Hendrik van Gilse (alias «Zuidema») wrote an extensive report for the Executive Committee of the Communist International (EKKI) where, in the best Communist tradition of self-criticism, he admitted that the Dutch contribution to the International Brigades left a lot to be desired, notwithstanding the heroic contributions of some individual soldiers. This report is key to the understanding of the causal relation between the Dutch crack-down on recruitment for the International Brigades and Dutch-German tensions in Spain.

«Zuidema», who had been sent on a fact-finding mission after the apparent failure of earlier attempts by the Dutch Communist Party to establish a permanent presence in Spain, ${ }^{45}$ admitted in his report that as a result of both the legal actions

43 ARCHo2806/6r: Interview Piet Laros, Io.4.I980.

44 See also the, somewhat rambling, interview with Frits Gunther, another Dutch IB volunteer, in M. Schouten, Voor de oorlog: herinneringen aan de jaren '30, Amsterdam 1982, 217-218, in which he complains about the «crazy» fanatical Germans and their militarism, citing their direct responsibility for getting a number of fellow Dutch volunteers thrown in jail for minute infractions of military discipline.

45 Two representatives, code-named «Winter» and «Summer», had been in Spain before, but neither 
taken by the Dutch government and the political climate turning against «foreign» political movements, recruitment efforts had suffered both quantitatively and qualitatively. Of the 350 Dutchmen who had travelled to Spain at the time «Zuidema» wrote his report, only I4I were battle ready. Some had been repatriated, were convalescing, or had died, but most of those inactive had either been sent to the rear areas by command staff (63) or had deserted (99). Both the relatively low number of Dutch recruits and the high desertion rate - especially when compared to Spanish Civil War volunteers from other small European countries, such as Norway or Switzerland - was due to the poor workings of the IRA recruiting apparatus, argued «Zuidema». It seems like the IRA cells responsible for recruiting was either partially immobilised by the fear of reprisals, or disrupted by arrests. This is evidenced by the distribution of recruits: About I2O of them hailed from Amsterdam - the site of the easily recognisable and locatable IRA headquarters -, whilst Rotterdam, which had a sizable local Communist Party presence but no official IRA buildings, only supplied 2I recruits. In order to fulfil their - self-imposed? - recruitment quota, the IRA had resorted to making grandiose promises to potential recruits, admitted «Zuidema»: Recruits were told that they were sent to do work in the navy and in factories, or they were promised a limited military service and regular leave. None of these promises could be delivered upon. Not surprisingly, the IRA did not feel that it had the luxury of assessing the potential recruits' military experience and/or aptitude. ${ }^{46}$ To make matters worse still, «Zuidema» conceded, Dutch CP members had been quite hesitant to journey to Spain. Out of the 350 Dutch combatants, only I4I were Dutch Communist Party members. Moreover, the majority of the Party recruits were recent junior party members, meaning that many more experienced members did not go to Spain or were not allowed to go by their local cadres. That even someone such as Leo Klatser, who was not a high-ranking communist at all but a lowly intern at the Volksdagblad, was sequestered from serving at the front is, in this regard, telling. ${ }^{47}$

But it was not only the recruiting that had suffered as a result of Dutch legal actions. The intense police and secret service scrutiny under which Dutch CP members were placed meant that official communication between Spain and the Netherlands was difficult at best. Fearing that telephone and mail conversations would be tapped, the Dutch CP relied on couriers to ferry messages written in invisible ink between the Netherlands and Spain. Couriers had to cross three borders illegally for a one-way trip from Spain to Holland, risking capture by border patrols each time.

seemed to have lasted very long. DNA.05.03/1672: Dutch Consulate Barcelona to Ministry of Foreign Affairs, II.9.I937; DNA 2.09.99/4: Report Amsterdam police, «Gegevens over Winter en Timmermans», undated.

46 RGASPI 545/6/399: Zuidema to EKKI, n.d. [No- vember I937]; Quotations from RGASPI 545/6/ 399: Zuidema to EKKI, n.d. [December I937].

47 RGASPI 545/6/400: «Bericht über den holländischen Personalbestand, n.d. [November/December I937]. 
Worse still, some Dutch IB men volunteered to carry messages only to defect the moment they reached the Netherlands. All in all, this method of Dutch-Spanish communication was slow and cumbersome at best, and unreliable and dangerous at worst. It also meant that the Dutch CP leadership in Amsterdam was kept in the dark about the goings-on in Spain, which is probably why «Zuidema» was sent on a fact-finding mission in the first place. Moreover, a lack of regular and reliable communication with the home front meant that it was nearly impossible to grant Dutch fighters leave. The CP had no way of reliably knowing who had been granted leave or for how long, and this meant that it was almost impossible to distinguish authorised from unauthorised leave. Finally, the communications apparatus, such as it was, was overburdened by the need to ferry Dutch recruits in Spain, who had been called up for military service or retraining exercises at home, back to the Netherlands. The CP and the IRA considered this of the utmost importance because it emphasised that fighting in Spain was perfectly compatible with the quintessential Dutch duty of fulfilling one's military service. ${ }^{48}$

The Dutch volunteer military effort in Spain was therefore undermined by a failed recruiting campaign, broken promises and imperfect communication with the home front, whilst those Dutchmen who had ventured out usually only had the most basic understanding of, and a distinct disinterest in, military matters. To make matters worse, reported «Zuidema», most of them lacked any experience of working together with others in larger units. A large majority had never been a member of a trade union, and had worked - if they had any work experience at all - only in smaller companies. 49

Given all of this, it is not surprising that the Dutch struck a poor figure with the hardened Germans from the Exil: «They reported for duty only grudgingly, were very unhappy and whined about wanting to go home», according to a late-I93 8 report. It is equally unsurprising that there were so few Dutch officers and political commissars: The Germans simply felt the Dutch were unsuitable or - even worse - unreliable, unless they were led by people who actually knew and understood what they were doing. Misunderstandings and the harsh treatment meted out to the Dutch by Germans who could not understand them (literally and figuratively) only served to worsen the situation. ${ }^{50}$

«Zuidema»'s reports to the Comintern attempted to place the blame for the poor Dutch showing in Spain on a lack of party work, and stressed the need for redoubled political education efforts both at home and abroad to counter the narratives now

48 NA 2.09.99/18I: Report Amsterdam police, «Gegevens over Winter en Postma, n.d. [I937]; NA 2.09.99/4: Report Amsterdam police, «Gegevens over Winter en Timmermans», undated.

49 RGASPI 545/6/399: Zuidema to EKKI, n.d. [November I937].
50 RGASPI 545/6/400: «Bericht über die holländischen Freiwilligen in der Zeit vom November I936 bis zu ihrer Zurückziehung», n.d. 
prevalent in Dutch political culture that focussed on the issues of national identity and character. However, the real culprits, according to «Zuidema», were the «traitors», «fifth columnists», «Fascists» and «Trotskyists» who had infiltrated the Dutch ranks in Spain..$^{1}$ This was demonstrably untrue, but the Dutch CP leadership had good reasons to place the blame elsewhere. Even before the Spanish Civil War, the Dutch CP enjoyed a peculiar reputation in Moscow. The Comintern secretariat habitually treated it as an unruly problem child, and when referring to the Netherlands, Comintern leaders such as Georgi Dimitrov made recurring references to what they called «the Dutch Problem». ${ }^{22}$ What exactly «the Dutch Problem» was, was never spelt out, but judging from the minutes of meetings between the EKKI and the members of the Dutch CP, this ailment seems to have consisted of a combination of apathy and sectarianism that was apparently inherent in Dutch communists. So little did the Comintern trust the Dutch CP to fix its own «Problem» that it even felt the need to micromanage the electoral caucus of Easter 1937, sending its leadership drafts of not only the caucus's programme but also the speeches party that the luminaries were supposed to give. ${ }^{53}$

It seems that «Zuidema»'s report was combined with fears of being even further marginalised by the Comintern secretariat to spurn the Dutch CP leadership to action. Their solution to the difficulties that the Dutchmen experienced in Spain was, interestingly, an acknowledgement that the Dutch simply could not meet the transnational ideal in practice. Their political and military experiences, the peculiar circumstances of Dutch recruitment and the particularly virulent language with which fighting for Spain was denounced in the mainstream press, simply set them too far apart from their fellow fighters. Therefore, the Dutch CP suggested that the Dutch should all be sequestered in their own unit, which they would run themselves and which would fight alongside, but not with, the German-speaking and -dominated units of the XI Brigade. It was therefore decided to send «mehr und bessere Holländer» to Spain, most likely via a process of internal mobilisation and a more stringent selection process. Sending «more and better» Dutchmen would allow the formation of a new unit at company level, led by experienced veterans assisted by newly arrived military experts and politically experienced commissars. «Dutchman Pete» - the highest-ranking Dutchman in Spain - was promoted to be its commander. ${ }^{54}$ In addition, Dutch staff and propaganda work would be strengthened - a process which had already begun in October when Dutch translations of the German-language IB newspaper began to appear. They would now feature - in addition to the translations of German articles on the Spanish situation - detailed reports on the goings-on in Holland as well as a Spanish language course by none other than the novelist Jef

51 Ibid.

52 RGASPI 495/I8, I230: Minutes EKKI, 21.I2.I937 and 22.I2.I937.

53 RGASPI 496/I8, I24I: «Einige Bemerkungen zur
Vorbereitung des Parteitages im April I938», 3I.3.I938 and 2I.4.1938.

54 RGASPI 545/6/399: Zuidema to EKKI, n.d. [December I937]. 
Last. ${ }^{55}$ Moreover, a new system of coded communication would be established, which would - it was hoped - enable Dutchmen to go on leave. ${ }^{56}$ Crucially, perhaps, the creations of a Dutch unit and of a Dutch hospital in Villanueva de la Jara were considered to be «propagandistisch [...] von sehr großem Wert». ${ }^{57}$ The process of transferring the majority of Dutchmen in Spain to the new Dutch unit, which was stationed at Villa Alba, was complete in early i938. It was christened the «Seven Provinces» Company, a name that harkened back to the Golden Age-era Republic of the Seven United Provinces and the Dutch Wars of Independence of the sixteenth and seventieth centuries, thereby implying a strong connection between the Dutch and the Spanish struggles for freedom. In order to further strengthen the unit, Dutch deserters in captivity were offered amnesty if they would fight with the «Seven Provinces», indicating the hope that their morale problems would disappear if they could just fight alongside and under their own people. ${ }^{58}$

\section{From Anti-Fascist War to Anti-Fascist Resistance}

After its formation, Dutch Company members were (re)trained along with the rest of the IB in preparation of the battle of the Ebro, which started in July I938. At the Ebro, the unit suffered heavy losses; it was withdrawn from the line in late September I938, after which it remained in reserve until the International Brigades were recalled following an agreement between the Spanish belligerents and the signatories of the Non-Intervention Agreement. 59 This agreement stipulated that the Dutch government would arrange for the transport of the approximately 200 survivors back to the Netherlands and refrain from prosecuting them under the Order in Council of June I937, which carried serious penalties, including lengthy prison sentences, for foreign fighting. The Dutch IB members would, however, lose their Dutch citizenship. $^{60}$

Upon their return home, the stateless IB veterans immediately became the subject of intense scrutiny from the intelligence services. It was hoped that questioning them would finally yield actionable proof of the links between the Communist party, the IRA, and the International Brigades, but most IB men kept their mouths firmly shut and the investigations petered out. This, however, did not stop the surveillance efforts: Intelligence services continued to visibly trail former IB men to make sure that they did not engage in political campaigning of any kind; they used this as an excuse to make sure that the ex-IB men were expelled from the CP and that their

55 A somewhat random collection of copies can be found in RGASPI 545/2, 426.

56 IISH ARCHo2806/04: Leo Klatser to Noord Klatser, 7.9.1937.

57 RGASPI 545/6/399: Zuidema to EKKI, n.d. [november I937].

58 IISH ARCHO2806/6r: Interview Piet Laros, I8.4. I980.
59 DNA 2.05.03/1678: Official report Noorscharwoude police, I3.2.1939.

60 DNA 2.09.99/II3: Foreign Affairs Ministry to Justice Ministry, 28.3.I938; NA 2.05.03/168I: Foreign Affairs Ministry to Justice Ministry, 2I.I.I939. 
speaking tours on Spain did not include any appeals for money, weapons or men on behalf of the now severely embattled Republic. ${ }^{61}$

Despite losing their Dutch passports, many former International Brigaders reported for national service in April I939 when the Dutch government mobilised its border forces. Using a legal loophole that allowed ex-citizens to join up, many unemployed IB veterans jumped at the chance of gainful employment guarding the Netherlands against a possible Nazi invasion. Since their service in Spain had always been framed as being in defence of the Netherlands - or even of a far more vague «Dutchness» -, there seemed to be no contradiction between serving in Spain and serving on the Dutch border. ${ }^{62}$ Naturally, this changed when the Dutch CP leadership announced the conclusion of the German-Soviet Nonaggression Pact on 24 August I939. Communist parties, including the Dutch CP, were instructed by the Comintern Secretariat that the Second World War, which was about to engulf Europe, was not a conflict pitting anti-fascists against fascists, but should be seen as an imperial struggle instigated by the ruling classes of all the capitalist countries, including not only Germany but also Britain and France. The EKKI added, in a directive to the Dutch CP, that Dutch communists should argue for continued strict neutrality, and that the former Interbrigaders should be dissuaded from joining the armed forces following their anti-Nazi sentiment. ${ }^{63}$

It does not seem to have mattered much to the Dutch Interbrigaders, especially those who had remained loyal to the Communist party. A partial explanation for this continued loyalty in the face of what might easily be construed as a betrayal of the anti-Fascist principles for which these Brigaders fought might lie in this fact: Simultaneously with the Comintern-ordered course correction, several leading Interbrigaders, including Jan Hendrik van Gilse («Zuidema»), Krijn Breur and Siep Adema, had been tasked with forming a secret party militia. This militia was to be activated in case the party should be forced underground. It consisted mainly of other Interbrigaders, who joined not just out of the continued loyalty to their fellow veterans, but out of economic motivations as well: Members of this underground society received some measure of pay out of the Dutch CP coffers. ${ }^{64}$ Crucially, however, the formation of this militia once again served to remind the former Interbrigaders that they had fought for the Netherlands in Spain, and that they would be asked to do so again.

61 DNA 2.09.45/1572: Public Prosecutor Amsterdam to Attorney General Amsterdam, 3I.7.I939; DNA 2.09.99/85: Report Police Investigation Department Utrecht, I3.3.I939, with enclosed Report Police Investigation Department Zeist, 20.2.I939, «Afschrift Rede van Petrus Laros, uitgesproken op een huishoudelijke algemeene ledenvergadering van het District Rotterdam der Communistische Partij Nederland op Woensdag 25 Januari I939 in gebouw 〈Odeon»», n.d.
62 IISH ARCHo2806/37: Interview Arie Favier, II.4.I985; IISH ARCHo2806/38: Interview Wim Jong, IO.I.I984.

63 IISH ARCHoo347/I739: Telegram Komintern, 8.9.1939.

64 IISH ARCHo2806/33: Interview Siep Adema, 25.5.I984. 
When Germany invaded the Low Countries and France on Io May I940 and the Netherlands surrendered five days later, the militia was not activated. ${ }^{65}$ This might seem surprising: Dutchmen, let alone Dutch communists, had little experience with war or occupation, so the first-hand knowledge that the IB veterans could bring to bear would have been tremendously valuable. ${ }^{66}$ However, despite the occupation of their homeland, the Comintern had counselled the Dutch CP that the German-Soviet pact remained in full force, and that no action could be undertaken to jeopardise it. Moreover, the Dutch CP, which was declared illegal alongside other political parties on 20 July I 940 and which subsequently moved underground, urged the former Interbrigaders to go into hiding. Some of them were too well-known and therefore posed a risk just as the party was transforming itself into an underground movement. «Dutchman Pete» Laros fled to France, for example, whilst others sought refuge in the countryside. ${ }^{67}$ Their experiences since returning to Spain had taught them that the Dutch government had kept close tabs and records on them, and many (rightly) concluded that these files would be available to the German occupier as well, meaning that they would be at great risk if the pact were broken. ${ }^{68}$

However, small sections of the underground militia, most notably those in The Hague, seemed to have activated themselves, aided by the fact that the CP control over their actions had been disrupted while it dismantled its formal party structure and built up its underground apparatus. When communication with local sections was re-established later in I940, the CP managed to bring them back in line. Its underground leadership emphasised that class issues were now paramount and attempted to turn its members' energies away from focussing on Germans and instead towards Dutch collaborators and the occupation itself. In effect, the CP argued that its members should protest against occupation, collaboration and «imperialist warfare», but not against the army doing the occupying, the occupational authorities with whom Dutchmen were collaborating, or the forces doing a significant amount of the imperialist war. This required a significant amount of mental gymnastics and, in many cases, monumental restraint. IB veteran Siep Adema, for example, later remembered feelings of great relief when in February I94I a large strike offered him the opportunity to join street gangs and to seek confrontations with both Dutch fascists and the SS. ${ }^{69}$ The strike had been organised by the CP, ostensibly to demand higher wages and the restoration of civil rights, but anger over German measures against the Amsterdam Jewry quickly took centre stage. The Germans retaliated by

65 R. Harthoorn, Vuile Oorlog in Den Haag. Bestrijding van het communistisch verzet tijdens de Duitse bezetting, Utrecht 20I3, 8I-85.

66 As suggested by D.van Galen Last, «The Netherlands», in: B. Moore (ed.), Resistance in Western Europe, Oxford, New York, 2000, I89-22I, I9I.

67 Interview Piet Laros with Cherry Duyns, I976 (http://www.geschiedenis24.nl/speler.program.70 3326r.html).

68 H. Galesloot/S. Legêne, Partij in het verzet. De CPN in de tweede wereldoorlog, Amsterdam I986, 22-24.

69 IISH ARCHo2806/33: Interview Siep Adema, 25.5.1984. 
rounding up known CP members, and would eventually do so again after the invasion of the Soviet Union on 22 June I94I finally removed any need for leniency against communists in occupied Western Europe. ${ }^{70}$ German roundups were, as the CP had feared, greatly aided by the intelligence gathered before the war by the Dutch secret services, and supplemented by new intelligence collected under the auspices of the German Polizeiführer in the Netherlands, Hans Rauter. Moreover, the police informants who had infiltrated CPN groups on the behest of the Dutch intelligence services prior to I940 would continue their work during the war, now reporting to Rauter or his subordinates. ${ }^{71}$ Unsurprisingly but tragically, Dutch Spanish Civil War veterans, who had been under heavy surveillance even before the German invasion and were considered extremely dangerous fanatics, were singled out for arrest. ${ }^{72}$

Those that had managed to elude police and SS forces were, following the dissolution of the pact, finally able to continue the fight against Fascism that had begun in Spain. Although some tried - understandably - to remain out of harm's way, most chose to fight. The I939 secret party militia members were sought out by the CP to join other communists with military experience to form an «underground second front», which would prepare the ground for an armed uprising. This so-called «Military Contact» or «Mil»-group, was led by «Zuidema». He was assisted by fellow Interbrigader Max Meijer and by Gerrit Kastein, a physician who had been sent to Spain by the IRA to serve in a Dutch ambulance. The «Mil»-group gained about 200 members in autumn I94I. ${ }^{73}$ Divided into small five-person cells, they committed acts of sabotage against weapons manufacturing plants, Wehrmacht and Luftwaffe ammo dumps and railway junctions. Meanwhile, Sally Dormits, a Rotterdam-based IB veteran, created his own communist-allied «Dutch People's Militia» and called on IB veterans in Rotterdam and The Hague. Disaster struck when Dormits was arrested on I7 October I942. A search of his house resulted in his address books being confiscated by Dutch police and the subsequent arrest of more than 600 of his contacts. Worse still, the arrests and interrogations - which frequently featured torture - led to further arrests. ${ }^{74}$ After I943, most of the IB men that had returned from Spain in late I938 or early I939 were either dead or incarcerated in a German concentration camp. When attempts were made after the defeat of Nazi Germany in May I945 to reconvene all members of the secret party militia that was made up of former International Brigadiers, only seventy out of the original 300 were still alive. ${ }^{75}$

70 B.von Benda-Beckmann, De Velser Affaire. Een omstreden oorlogsgeschiedenis, Amsterdam 2013, IO3I05.

71 IISH ARCHoo347/I27: Statement P.Wapperom, n.d. [I945].

72 NIOD Institute for War, Holocaust and Genocide Studies, Amsterdam (NIOD), Gen. Komm. für das Sicherheitswesen, 77, inv. nr. IIıо: Report SS-Haupt- sturmführer Munt to Reichssicherheitshauptamt I2.I.I944.

73 IISH ARCHoo347/808: Statement Max Meijer, 4.4.1958.

74 Galesloot/Legêne, Partij in het verzet, Io8-I20.

75 IISH ARCHo2806/37: Interview Arie Favier, II.4.I985. 


\section{Conclusion: A Trans-National Army?}

By focusing squarely on the Dutch Interbrigadiers' experiences, both in Spain and in German-occupied Holland, this article has flown somewhat in the face of an historical trend. It has highlighted the following elements as key explanations in analysing the trajectories of Dutch International Brigaders: the Dutch political culture, the specific legal regime created in the Netherlands in response to the formation of the International Brigades in Spain; and the peculiar position of the Dutch CP both in the Dutch political landscape and within the Comintern. It was not my aim to suggest that all analyses of the International Brigaders or their return trajectories should be national rather than transnational. Rather, I strongly believe an approach such as the one demonstrated in this article can highlight something absolutely crucial about transnational armies, and about transnational movements in general: namely the tensions, conflicts and compromises that are at their core.

These become apparent firstly when discussing the identity of transnational movements. The Dutch recruitment campaign for the International Brigades quickly became embroiled in a debate not only on the Dutch national identity, which deeply influenced the content of the mobilisation messages that it distributed, but also on the expectations of the Dutchmen volunteering for Spain. Tensions between the Dutchmen who arrived in Spain in 1936 and 1937 and their cobelligerents quickly came to the fore after the International Brigade leaderships decided to post Dutch volunteers with German units. The Dutch recruits' expectations and abilities clashed with those of the hardened German Exil veterans. Rather than transnationally connecting with the Germans, many Dutch recruits felt that they were unable to understand their German counterparts and superiors. They did not speak the language, were frightened by the German militarism and fatalistic determination, and were frustrated by the lack of advancement opportunities and the understanding of their wants and needs. Meanwhile, the disruption of the Dutch recruitment network by the Dutch security services meant that these concerns were only belatedly received by the Dutch CP leadership. Already ostracised by the Comintern, they took immediate but nevertheless belated action. Forming a specific Dutch company, and supported by Dutch officers, Dutch political commissars, and even a special Dutch soldier's newspaper, they tacitly acknowledged the failure of the transnational integrative efforts of the International Brigades. Upon their return in the Netherlands, the effects of the legal regime created to stop recruitment for Spain continued to play a key role in their return trajectories even long after the Spanish Civil War was lost to the Republics. After May I940, the detailed records that the Dutch security services collected about them fell into the hands of the German occupying forces, who eagerly made use of them in their prosecution of Dutch CP members in the wake of the February I94I strike. This meant that the Dutch Civil War volunteers were not able to play a leading role in the Dutch resistance; most of those who had survived the first two waves of arrest were caught and either killed or put in concentration camps in I943. 
My analysis suggests that further research into the International Brigades - and other forces made up of «foreign fighters», such as the IS - would do well to consider that these forces cannot possess a single, distinctive and collectively transnational identity, despite their own propagandistic efforts to prove the opposite. The examples provided in this article regarding the Dutch role in the International Brigades suggest that transnational armies might be construed rather as possessing different identity layers that can, but need not, be mutually exclusive, and are linked to elements of different national and/or military cultures. This would allow us to analyse the way in which these different elements within a transnational army not only clashed and conflicted, but also combined in directed and unexpected ways, thereby producing uniquely dynamic military forces such as the International Brigades.

\section{Struggling to Fit In. The Dutch in a Transnational Army, 1936-1939}

The Spanish Civil War (1936-1939) possessed a transnational resonance that echoed far beyond the borders of the country in which it was fought. It drew thousands of foreign fighters to Spain where, as many believed, the future of Europe would be decided. Most of them fought on the side of the embattled Republican government against an uprising supported by international Fascism. Given the foreign fighters' similar socio-economic backgrounds and shared anti-Fascist sentiment, historians have suggested that the «International Brigades», formed out of these foreign fighters, constitute a true transnational army. This article suggests, however, that many of these foreign fighters had real trouble forging a transnational connection with their fellow fighters. Focusing on Dutch Interbrigadiers, it further highlights how the specificities of Dutch political culture and the legal regime created in the Netherlands combined to create a unique set of circumstances that impeded Dutch foreign fighters' abilities to effectively work together with their German colleagues in Spain and their post-Spanish Civil War efforts to resist the Nazi occupation of the Netherlands. This article suggests, therefore, that the International Brigades do not possess a single, distinctive and collectively transnational identity. Rather, they are made up of different identity layers that can, but need not, be mutually exclusive, and are linked to elements of different national and/or military cultures.

\section{Samuël Kruizinga}

University of Amsterdam

Kloveniersburgwal 48

NL-1012 CX Amsterdam

s.f.kruizinga@uva.nl 